University of Arkansas at Little Rock William H. Bowen School of Law Bowen Law Repository: Scholarship \& Archives

Faculty Scholarship

1977

\title{
Constitutional Rights and Land Use Planning: The New and the Old Reality
}

Robert R. Wright

Follow this and additional works at: https://lawrepository.ualr.edu/faculty_scholarship

Part of the Constitutional Law Commons, and the Property Law and Real Estate Commons

Recommended Citation

Robert R. Wright, Constitutional Rights and Land Use Planning: The New and the Old Reality, 1977 Duke L.J. 841 (1977).

This Article is brought to you for free and open access by Bowen Law Repository: Scholarship \& Archives. It has been accepted for inclusion in Faculty Scholarship by an authorized administrator of Bowen Law Repository: Scholarship \& Archives. For more information, please contact mmserfass@ualr.edu. 


\title{
CONSTITUTIONAL RIGHTS AND LAND USE PLANNING: THE NEW AND THE OLD REALITY
}

\author{
Robert R. Wright*
}

Controls on the private use of land are not of recent vintage-they go back at least to the Romans, ${ }^{1}$ if not into the darker past, and find expression in various statutes and judge-made doctrines of centuries ago. ${ }^{2}$ Despite Blackstone's overly broad pronouncement that private property rights could not be violated "even for the general good of the whole community,"3 property rights had in fact been limited for centuries before Blackstone's

* Donaghey Distinguished Professor of Law, University of Arkansas, Little Rock; former Dean and Professor of Law, University of Oklahoma. B.A., 1953, J.D., 1956, University of Arkansas; M.A., 1954, Duke University; S.J.D., 1967, University of Wisconsin.

1. The Twelve Tables, the earliest code of Roman law, provided that

[w] hoever sets a hedge around his land shall not exceed the boundary; in the case of a wall, he shall leave one foot; in the case of a house, two feet. . . . If a well, a path, an olive or fig tree, nine feet. Finally, whoever plants other trees shall leave a space of five feet between [his] property and his neighbor's. If there is litigation about boundaries, five feet.

Treasury of Law 71 (Nice ed. 1964)(Law X). The Twelve Tables were drafted in 451-450 B.C. Id. 69.

2. For example, the Statute of Winchester, $1285,13 \mathrm{Edw}$. 1, Stat. 2, c. 5 required that highways from one market town to another be enlarged and bushes and trees within a certain distance of the road be removed in order that no one could "lurk to do hurt" within a certain distance of the right of way. Any landowner who failed to cut down the underbrush might be held liable for any resulting robbery and fined by the king for any resulting murder. In the time of Elizabeth I, the cutting of trees around London as fuel for the iron mills led to the imposition of limits on this activity. 23 Eliz. 1, c. 5 (1581). After the great fire which destroyed much of London in the 17th century, an act was passed which provided building regulations intended to prevent such a calamity in the future. 19 Car. 2, c. 3 (1666).

The common law doctrines of waste and nuisance are limitations on the use of land which have long been an accepted part of our property law. The Statute of Marlborough of 1267, although predated by common law notions of waste, prohibited waste generally. $52 \mathrm{Hen} .3, \mathrm{c}$. 23 (1267). For a discussion of the development of the law in America, see Sherrill v. Connor, 107 N.C. 630, 12 S.E. 588 (1890); Melms v. Pabst Brewing Co., 104 Wis. 7, 79 N.W. 738 (1899); and 5 AMERICAN LAW OF PROPERTY \$20.12 (A.J. Casner ed. 1952). Nuisance also had an ancient lineage, and it began to take on a clearer form of its own when the assizes of novel disseisin and nuisance were separated during the reign of Henry II. See T. PluCKNeTt, A CONCISE HISTORY OF THE COMMON LAW 372 (5th ed. 1956). The law of nuisance has developed to the point in the United States that in some jurisdictions it has formed the basis for holding that when the nuisance is created by a governmental agency, the result may be the equivalent of condemnation of the affected land. See, e.g., Thornburg v. Port of Portland, 223 Ore. 178, 376 P.2d 100 (1962); Martin v. Port of Seattle, 64 Wash. 2d 309, 391 P.2d 540 (1964), cert. denied, 379 U.S. 989 (1965).

3. $1 \mathrm{~W}$. BLACKSTONE, COMMENTARIES* 139. But Blackstone was talking about the inherent right of Englishmen to own property, and he earlier had stated that property could be used and enjoyed "without any control or diminution save only by the laws of the land." Id. 138 (emphasis added). 
time by Parliament and the judiciary in England. ${ }^{4}$ This tendency toward controls passed rather easily into the American experience ${ }^{5}$ with the result that, despite American declarations somewhat similar to Blackstone's, ${ }^{6}$ we not only have restricted the use of land when the public welfare demanded it, ${ }^{7}$ but we have also used land itself as an asset in achieving national goals. ${ }^{8}$ The idea that rights in land are absolute, finding expression in the "life, liberty and property" trilogy of John Locke and the authors of the Constitution, ${ }^{9}$ was modified early in our history by the recognition that property is a resource as well. As such, although title to it has been protected even in extreme situations, as it was in the Supreme Court's decision to favor bona fide purchasers in Fletcher $v$. Peck,${ }^{10}$ property rights have never been so

4. See note 2 supra.

5. For example, in the Acts and Resolves of the Province of Massachusetts Bay of 169293, ch. 23 (1692), there is an act designed to prevent nuisances arising from slaughterhouses, still-houses, tallow chandlers, and curriers; and New York in 1807 passed a law providing for the laying out in New York City of streets and roads. N.Y. LAws ch. 115 (1807). The English common law and many of the enactments of Parliament passed into American law through the various state reception statutes. See, e.g., ARK. STAT. ANN. § 1-101 (1956 Repl.); Mo. REv. STAT. \& 1-010 (1969).

6. There are many overly broad statements about the sanctity of property rights, but few go as far as article 2, section 22 of the Arkansas Constitution, adopted in 1874 and still in effect, stating that "the right of property is before and higher than any constitutional sanction." ARK. CONST. art. 2, § 22.

7. The entire conservation movement of the early twentieth century as well as the current ecological concern with protecting and preserving our natural environment are large scale examples of putting the public welfare before property rights. This principle, of course, underlies the concept of public nuisance law.

8. This is illustrated by the Ordinance of 1785 , enacted under the Articles of Confederation, which laid the basis for establishing title to land lying west of the original colonies, thereby helping to ease the problem of conflicting claims. The Ordinance prevented conflict in the west by providing for title to be deraigned from the central government, paid off the moral obligation of the country to the soldiers of the revolution by providing land for them, promoted settlement of the western lands, derived some income for the government from land sales, encouraged a certain amount of commercial activity based on land speculation, retained a potential source of income and wealth through retention of some valuable mineral rights, and provided for schools. This was an early example of the use of the police power on a wide scale. See generally Wright, The Relation of Law to Socioeconomic Change, 28 ARK. L. REV. 440 (1975), reprinted in IssuES AND IDEAS IN AMERICA: 1776-1976, at 47 (B. Taylor \& T. White eds. 1976). Similarly, systematic land grants were used to encourage the expansion of the railroads.

9. U.S. CoNST. amends. V, XIV. John Locke stated that man is in danger in a state of nature and enters into society "with others, who are already united, or have a mind to unite, for the mutual preservation of their lives, liberties, and estates, which I call by the general name, property." Locke, An Essay Concerning the True Original, Extent and End of Civil Government, in English Philosophers from Bacon to MiLl 403, 453 (Burtt ed. 1939) (Second Treatise of Civil Government). Moreover, Locke seemed to consider property to be the most inviolable of the three and gives the example that although a sergeant can command a soldier to go on a suicide mission, he cannot take without consent one penny of the soldier's money. Id. 460 .

10. 10 U.S. ( 6 Cranch) 87 (1810). This case involved a corruptly secured grant of land by the Georgia legislature. The legislature later tried to recover the land, which was by then owned by 
absolute that they have been allowed to subvert the economic needs of a community or stifle technological growth. For example, in Charles River Bridge v. Warren Bridge ${ }^{11}$ the property rights of the owners of the bridge had to give way to community needs and market demands. Moreover, no compensation was awarded to the holders of the bridge franchise because that might have affected adversely the growth of the railroad industry. ${ }^{12}$

Land was controlled as well by the courts through the doctrines of nuisance and waste. Whenever the principle of sic utere tuo ut alienum non laedas ${ }^{13}$ entered the picture on behalf of an aggrieved landowner, it meant that property rights were not absolute. If no man could use his land in such a way as to injure his neighbor, the result was that his neighbor had something similar to an implied easement restricting nearby land uses. Moreover, if the heralded Blackacre's life tenant had to answer to the remainderman for his use while in possession, then he was not absolutely free to use the property as he might choose.

It was not a difficult step to move from the concept of judicial controls grounded in nuisance concepts to ordinances based on the police power and bearing a resemblance to statutory nuisance controls. In the early twentieth century cases of Hadacheck v. Sebastian ${ }^{14}$ and Reinman v. City of Little Rock, ${ }^{15}$ the United States Supreme Court confronted and approved such ordinances. After that, it was a leap, but not quite so giant a leap as it might have seemed, to approve a more complex, comprehensive zoning ordinance such as that approved in the landmark case of Village of Euclid v. Ambler Realty $\mathrm{Co}^{16}$ The ordinance was upheld against a landowner's claims that it amounted to an unconstitutional taking which deprived him of liberty and property without due process of law and that it also denied him equal protection. ${ }^{17}$ The conscience of the essentially conservative judge who

purportedly innocent purchasers, but the Court held that the contract clause prevented the legislative annulment of their titles.

11. 36 U.S. (11 Pet.) 420 (1837).

12. Chief Justice Roger B. Taney stated for the majority:

In some cases, railroads have rendered the turnpike roads on the same line of travel so entirely useless, that the franchise of the turnpike corporation is not worth preserving. Yet in none of these cases have the corporation [sic] supposed that their privileges were invaded, or any contract violated on the part of the state.

Id. at 550-51.

13. The maxim means that no one may use his property in such a way as to injure the person or property of another. This is the underlying principle of the law of nuisance. See Bove v. Donner-Hanna Coke Corp., 236 App. Div. 37, 258 N.Y.S. 229, 231 (1932).

14. 239 U.S. 394 (1915) (ordinance prohibited the operation of a brick yard or brick kiln within city limits).

15. 237 U.S. 171 (1915) (ordinance prohibited the conduct of a livery stable business in certain parts of the city).

16. 272 U.S. 365 (1926).

17. At issue was a comprehensive zoning ordinance which regulated such factors as the height of buildings, their use, and the minimum size of lots and structures, and thereby 
wrote for the majority was assuaged by the thought that such an ordinance would actually preserve property values. ${ }^{18}$

The exercise of public power to control land, therefore, existed long before the New Deal. Moreover, it was a power that had been utilized for honorable purposes-to promote the general welfare of the community, including its health, safety and morals; to preserve the value of property; and (although this was not recognized as a valid purpose standing alone) to enhance the beauty of the community and the surrounding area. ${ }^{19} \mathrm{An}$ entirely new profession, the planners, emerged. ${ }^{20} \mathrm{New}$ planning devices and concepts were devised to improve and provide flexibility in community development. ${ }^{21}$ Whatever its success, the intention behind land planning was and is admirable and the aims desirable.

But there are other values as well to which our society accords a high priority. It is not purely a matter of individual property rights being balanced against and occasionally coming into conflict with the public right to control or limit individual land use. There is the added problem of the effect these controls have on other asserted individual rights, including the rights of people of limited income, often members of a racial minority, to find housing in particular geographical areas and the rights of all people to move

prohibited the construction of apartment buildings in areas zoned "residential." In rejecting the landlord's claims, the Court announced that zoning ordinances will be declared unconstitutional only when they are "clearly arbitrary and unreasonable, having no substantial relation to the public health, safety, morals, or general welfare." Id. at 395.

18. Justice Sutherland referred to apartments in a single-family residential area as "mere parasites" and stated that the coming of apartment houses to such an area would ultimately déstroy "the residential character of the neighborhood. . . . Under these circumstances, apartment houses, which in a different environment would be not only entirely unobjectionable but highly desirable, come very near to being nuisances." 272 U.S. at 394-95. The attitude of the time was geared toward thinking primarily of "residential" as meaning single-family residential.

19. See note 29 infra.

20. On the planning profession generally, see PRINCIPLES AND PRACTICE OF URBAN PLANNING (W. Goodman ed., 4th ed. 1968); Care, The City Planner and the Unauthorized Practice of Law, 2 LAND Use Controls Q. 23 (1968). The New Jersey Supreme Court had occasion to consider the status of planners in New Jersey Chapter, Am. Inst. of Planners v. New Jersey State Bd. of Professional Planners, 48 N.J. 581, 227 A.2d 313, appeal dismissed, cert. denied, 389 U.S. 8 (1967).

21. Planned unit development and cluster zoning blossomed during the 1960's and are devices often utilized today. See, e.g., Chrinko v. South Brunswick Township Planning Bd., 77 N.J. Super. 594, 187 A.2d 221 (1963) (upheld ordinances permitting cluster and open space zoning). A few years later, New Jersey adopted a Planned Unit Development Act. N.J. STAT. ANN. $\S \S 40: 55-54$ to -66 . (West 1967) (repealed in 1975 and now a part of $\$ \S 40: 55 D-38 D-41$ ) (West Supp. 1977). See generally 2 N. Williams, AmERICAN Land PlanNing LaW $\$ \$ 48.01-.12$ (1974); Symposium: Planned Unit Development, 114 U. PA. L. REV. 3 (1965). The floating zone was another device which received less widespread acceptance, although upheld in Maryland and New York. Huff v. Board of Zoning Appeals, 214 Md. 48, 133 A.2d 83 (1957); Rodgers v. Village of Tarrytown, 302 N.Y. 115, 96 N.E.2d 731 (1951). Pennsylvania invalidated this device as constituting spot zoning in Eves v. Zoning Bd. of Adjustment, $401 \mathrm{~Pa} .211,164$ A.2d 7 (1960). 
from place to place. All zoning provisions as well as other forms of land use controls are exclusionary in one way or another, and thereby limit the rights of certain individuals to move into a particular area, but the issue remains as to how exclusionary they can be and still survive constitutional review. To put it another way, what forms of exclusion are legitimate and what forms are not? In deciding these questions, the courts, both federal and state, have had to choose between two important values: the public right to control the use of land for the public benefit under the police power and individual civil rights of due process and equal protection under the federal and state constitutions as well as the right to travel freely. The traditional challenge to a zoning provision as being such an arbitrary and unreasonable use of the police power as to amount to a taking, while continuing as the basis for most litigation, no longer stood alone by the mid-1970's. The new challenges to land use controls were predicated upon the alleged violation of fundamental, constitutionally protected civil rights. Thus, a new dimension to the due process question has been created, and the results have been conflicting. ${ }^{22}$ It is the purpose of this Article to attempt to categorize these developments and to analyze what currently appears to be constitutionally acceptable.

\section{THE ROAD TO Mount Laurel}

Two cases of the 1970's, Golden v. Planning Board ${ }^{23}$ and Construction Industry Ass'n v. City of Petaluma, ${ }^{24}$ are illustrative of the current situation. The problem both cases deal with is one which is endemic to large urban areas. A huge central city forms the nucleus for the metropolitan region. It is rotting away at the core, with its central business districts surrounded by slums or deteriorating tenements, and its businesses and more affluent citizens fleeing to the suburbs. Urban renewal and slum clearance projects have failed to stem the tide, with the result that most of the whites and the better educated and better paid minorities have departed. Following them is not a difficult decision for the downtown stores with wealthier and middle-income clientele. By retreating to suburban shopping centers, they

22. In Construction Indus. Ass'n v. City of Petaluma, 522 F.2d 897 (9th Cir. 1975), cert. denied, 424 U.S. 934 (1976) and Golden v. Planning Bd., 30 N.Y.2d 359, 334 N.Y.S.2d 138, 285 N.E.2d 291 (1972), appeal dismissed, 409 U.S. 1003 (1972), courts approved limitations of the rate of city growth which coincided with the construction of new public facilities and the provision for new services. But when cities have attempted to limit growth by zoning for only single-family dwellings situated on large lots, the courts have divided. Compare Valley View Village v. Proffett, 221 F.2d 412 (6th Cir. 1955) (Stewart, J.) and Cadoux v. Planning \& Zoning Comm'n, 162 Conn. 425, 294 A.2d 582, cert. denied, 408 U.S. 924 (1972) (held valid) with Appeal of Girsh, 437 Pa. 237, 263 A.2d 395 (1970) (held invalid).

23. 30 N.Y.2d 359, 334 N.Y.S.2d 138, 285 N.E.2d 291 (1972). See note 22 supra for a discussion of the case.

24. 522 F.2d 897 (9th Cir. 1975), cert. denied, 424 U.S. 934 (1976). See note 22 supra for a discussion of the case. 
are not only pursuing the people to whom they sell, but are also escaping the higher taxes, the increased crime, the congestion and the generally unpleasant environment of the central city. Nor is the decision by businesses to move out of the city a difficult one since many of the people who control them live in the suburbs. If Pepsi-Cola can function as effectively and sell as many Pepsis by having its main headquarters closer to Rye and White Plains than to midtown Manhattan, then why not?

This was the movement of post-World War II America, and it was a movement which accelerated during the tensions and strife of the middle to late 1960 's. ${ }^{25}$ It was surely not slowed by the northward spread of school desegregation and court-ordered busing. As many of the more affluent headed for the suburbs, the ability of the central city to maintain public services diminished. And the more the problem was dealt with through increased taxation, the more people retreated from it if they had the income to do so.

But the problems of the central city were at least in part being transferred to the suburbs. What had been small outlying communities found themselves being inundated with more people than they could accommodate. Suddenly there were not enough schools, not enough policemen, not enough fire stations, not enough available water and sewers, not enough streets or utilities to handle the influx. These little towns were becoming satellite cities; they found themselves "in the path of development.",26

Confronted with such a predicament, these satellite communities were faced with two threshold questions: First, could the community increase its public facilities and services rapidly enough to accommodate this growth, and second, even if that appeared possible, did the community want to try to absorb so many people? If either or both questions were answered negatively, the planners, lawyers and town fathers turned first to certain land use devices which were a natural outgrowth of zoning and which also found a parallel in subdivision development. The natural result of the use of such devices would be a limitation on growth. For example, if this were a suburban community which had existed largely as a "bedroom community"

25. See generally Chandler, Fair Housing Laws: A Critique, 24 HaSTings L.J. 159, 169-71 (1973).

26. In Lionshead Lake, Inc. v. Township of Wayne, 10 N.J.165, 89 A.2d 693, 697, appeal dismissed, 344 U.S. 919 (1953), reference was made to the township lying "in the path of the next onward wave of suburban development." In National Land \& Inv. Co. v. Kohn, $419 \mathrm{~Pa}$. 504, 519, 215 A.2d 597, 605 (1965), it was stated that the township was "in the path of a population expansion." The Pennsylvania court declared, "The question posed is whether the township can stand in the way of the natural forces which send our growing population into hitherto undeveloped areas in search of a comfortable place to live. We have concluded not." Id. at 532, 215 A.2d at 612 . In Southern Burlington County NAACP v. Township of Mt. Laurel, 67 N.J. 151, 160, 336 A.2d 713, 717 (1975), appeal dismissed, 423 U.S. 808 (1976), the New Jersey Supreme Court stated that Mt. Laurel lay "in the path of inevitable future . . . growth." 
for those who worked in the central city, it might elect to zone predominantly or even entirely for single-family dwellings, located on lots of substantial size, with square-foot requirements relating to the size of the structure. In addition, it might impose setback lines and side lot requirements. The obvious results would be a relatively low population density due to the exclusion of multi-family housing and mobile homes, a limitation on the types of people who could come into the community (because persons of low and moderate income probably could not afford to live there) and a lessening of the demands on community facilities and services in most communities experiencing an influx of white collar, middle and higher income families. Other results would include the maintenance of overall property values combined with an increased property tax base due to the construction of substantial houses on large lots, and, in general, the maintenance of essentially the same type of community which had attracted the people who came earlier.

These types of limitations, utilizing the police power, bear a striking similarity to the restrictive covenants employed in private subdivision developments. ${ }^{27}$ In essence, the municipal government imposed on all or part of the community what it viewed to be the desirable aspects of expensive subdivision developments. The courts generally agreed that this did constitute a valid exercise of the police power: ${ }^{28}$ if the population were less dense, there would be less traffic (which meant greater safety), less danger from fire in general and less danger of fires spreading when they occurred (which meant greater safety), pleasant neighborhoods consisting of large houses on wide lots (which supposedly enhanced the mental health of the residents), a protection of property values (which was in the general welfare), and various aesthetic benefits (which were legitimate to take into account as long

27. See generally J. Beuscher, R. WRight \& M. GITLEMAN, LAND USE 212-23 (2d ed. 1976); Lundberg, Restrictive Covenants and Land Use Control: Private Zoning, 34 MONT. L. Rev. 199 (1973); Note, An Evaluation of the Applicability of Zoning Principles to the Law of Private Land Use Restrictions, 21 U.C.L.A. L. REV. 1655 (1974). There is really little difference between restrictive covenants imposed by a private developer and zoning regulations relating to setback lines, lot size, house size and the like, except that one is a property right while the other is a municipal regulation.

28. Minimum lot sizes, although occasionally held to be too large to relate to the police power, have been sustained in many cases, including Senior v. Zoning Commission, 146 Conn. 531, 153 A.2d 415 (1959); Flora Realty \& Inv. Co. v. City of Ladue, 262 Mo. 1065, 246 S.W.2d 771, appeal dismissed, 344 U.S. 802 (1952); Fischer v. Township of Bedminster, 11 N.J. 194, 93 A.2d 378 (1952); and Franmor Realty Corp. v. Westbury, 280 App. Div. 945, 116 N.Y.S.2d 68 (1952). Minimum sizes of buildings have been upheld in a number of cases, but the landmark decision is Lionshead Lake, Inc. v. Township of Wayne, 10 N.J. 165, 89 A.2d 693 (1953), appeal dismissed, 344 U.S. 919 (1953). On this subject, see Babcock, Classification and Segregation Among Zoning Districts, 1954 U. ILL. L.F. 186, and compare Williams \& Wacks, Segregation of Residential Areas Along Economic Lines: Lionshead Lake Revisited, 1969 Wis. L. REv. 827. See text accompanying notes $46-54$ infra for discussion of minimum size requirements for buildings. 
as there were other benefits accompanying them). ${ }^{29}$ There would also not be very many minorities, poor people, or assorted undesirables-but the courts did not consider this result until more recently.

The earlier cases concerned situations in which the satellite communities had utilized these traditional forms of land use controls. These requirements are sometimes called "the zoning envelope" in that they represent a dimensional model which dictates the location, size and shape of the structure as well as the size of the lot: Most zoning laws in the United States today include regulations concerning the size and height of structures, the amount of the lot which is subject to occupancy, setback lines and open spaces. ${ }^{30}$ This Article, however, will concentrate on three devices: the regulation of minimum lot sizes, the regulation of the minimum square feet in a house and restrictive use limitations.

\section{Minimum Lot Sizes}

A leading case on minimum lot areas is Simon $v$. Town of Needham, ${ }^{31}$ which was decided almost thirty-five years ago by the Supreme Court of Massachusetts and which upheld a one-acre minimum. It was a valid exercise of the police power, said the court, to establish

a neighborhood of homes in such a way as to avoid congestion in the streets, to secure safety from fire and other dangers, to prevent overcrowding of land, to obtain adequate light, air and sunshine, and to enable it to be furnished with transportation, water, light, sewer and other public necessities, which when established would tend to improve and beautify the town and would harmonize with the natural characteristics of the locality. . . . 32

29. Generally speaking, most courts will not uphold an ordinance which is founded entirely upon aesthetic considerations, but will uphold an aesthetically beneficial ordinance if, in addition, it has more traditional police power justification. Compare People v. Stover, 12 N.Y.2d 462, 240 N.Y.S.2d 374, 191 N.E.2d 272, appeal dismissed, 375 U.S. 42 (1963) (which upheld an ordinance based on aesthetics alone) and Jefferson County v. Timmel, 261 Wis. 39, 51 N.W.2d 518 (1952), with State ex rel. Saveland Park Holding Corp. v. Wieland, 269 Wis. 262, 69 N.W.2d 217, cert. denied, 350 U.S. 841 (1955). See Note, Aesthetic Zoning: A Current Evaluation of the Law, 18 U. FLA. L. REv. 430 (1965). Justice Douglas has expressed the view that decisions based on aesthetic considerations are within the scope of the police power. Berman v. Parker, 348 U.S. 26, 33 (1954). See note 63 infra.

30. See Norwood Heights Improvement Ass'n v. Baltimore, $191 \mathrm{Md} .155,60$ A.2d 192 (1948); note 28 supra. On the height of structures, a fairly recent case sustaining building height regulations is City of St. Paul v. Chicago, St. P., M. \& O. Ry., 413 F.2d 762 (8th Cir.), cert. denied, 396 U.S. 985 (1969). See also the interesting case of Cobble Close Farm v. Board of Adjustment, 10 N.J. 442, 92 A.2d 4 (1952), involving a group of buildings clustered together which could not be developed for single-family use due to lot-size, set-back and floor area requirements (and which might have been permitted today under the cluster zoning concept).

31. 311 Mass. 560,42 N.E.2d 516 (1943).

32. Id. at 563,42 N.E. $2 \mathrm{~d}$ at 518 . 
If a reasonable minimum lot size would facilitate the alleviation of these concerns, then it was appropriate to use the police power in this fashion. But the Massachusetts court added this caveat:

A zoning by-law cannot be adopted for the purpose of setting up a barrier against the influx of thrifty and respectable citizens who desire to live there and who are able and willing to erect homes upon lots upon which fair and reasonable restrictions have been imposed nor for the purpose of protecting the large estates that are already located in the district. The strictly local interests of the town must yield if it appears that they are plainly in conflict with the general interests of the public at large, and in such instances the interest of "the municipality would not be allowed to stand in the way. . . ."We assume in favor of the petitioner that a zoning by-law cannot be used primarily as a device to maintain a low tax rate. It does not appear that it was so used here. ${ }^{33}$

Over two decades later, in Aronson v. Town of Sharon, ${ }^{34}$ Massachusetts invalidated a zoning provision involving lots of 100,000 square feet in size with a width of not less than 200 feet. "All that has made Sharon beautiful" would be promoted, it was argued on behalf of the town, and "amenities that are fundamental to mental and physical health" would be encouraged. ${ }^{35}$ But the Massachusetts court felt that these lots were unreasonably large and that the police power had been overextended to the point that this would amount to a taking without compensation. However, the earlier statement in the Simon case about the potential exclusionary effect of such provisions did not form the basis for the Aronson decision. -

Many courts had considerably less difficulty in sustaining large lot sizes, and during the 1950's and 1960's most jurisdictions upheld these large lot minimums. ${ }^{36} \mathrm{~A}$ three-acre minimum in the "finest residential development of the entire metropolitan area" of St. Louis was upheld. ${ }^{37}$ Fifteen years after that case, in 19.67, the, Maryland Court of Appeals upheld a county zoning ordinance providing for five residential zones, one of which covered a wide area and imposed a five-acre minimum lot size. ${ }^{38}$ The

33. Id. at 565-66, 42 N.E.2d at 519 .

34. 346 Mass. 598, 195 N.E.2d 341 (1964). The action had been brought by a developer who owned a large tract in Sharon. When he purchased the tract, existing zoning would have allowed a subdivision into forty-five lots; under the new zoning, the tract would yield only twenty lots. Id. at $600-01,195$ N.E.2d at 341 .

35. Id. at 603-04, 195 N.E.2d at 345.

36. See, e.g., Senior v. Zoning Comm'n, 146 Conn. 531, 153 A.2d 415 (1959); Bilbar Constr. Co. v. Board of Adjustment, $393 \mathrm{~Pa} .62,141$ A.2d 851 (1958); Franmor Realty Corp. v. Village of Old Westbury, 280 App. Div. 945, 116 N.Y.S.2d 68 (1952); Gignoux v. Kings Point, 199 Misc. 485, 99 N.Y.S.2d 280 (Sup. Ct. 1950).

37. Flora Realty \& Inv. Co. v. City of Ladue, 262 Mo. 1065, 246 S.W.2d 771, appeal dismissed, 344 U.S. 802 (1952).

38. County Comm'rs of Queen Anne's County v. Miles, 246 Md. 355, 228 A.2d 450 (1967), noted in 28 MD. L. REv. 90 (1968). 
Maryland court was not impressed by the argument that only " 'substantial' people, of 'more than ample' financial resources" could afford such lots. In addition to the concern over certain historic sites, the court cited testimony that it was worthwhile to attract people "of means" to the community, that tourism would be promoted, that such zoning was reasonable for a rural county in an otherwise urban area because it would preserve the character of the area, and that health and safety would be promoted by alleviating traffic and sanitation problems. ${ }^{39}$

One of the first decisions against large lot minimums was the Virginia Supreme Court invalidation of a two-acre minimum. ${ }^{40}$ The requirement had been imposed on about two-thirds of a county which was experiencing rapid growth, but the court felt that the primary effect was to prevent low income people from living in that part of the county. This case harkened back to the caveat of the Massachusetts court in Simon v. Needham. Probably, however, the most influential blow was struck in 1965 by the Pennsylvania Supreme Court in National Land \& Investment Co. v. Kohn. ${ }^{41}$

In National Land, subdivision developers, not minorities or low income groups, were the complaining parties. This case involved an eightyfive acre tract the value of which had been diminished substantially when the lot minimum was increased from one acre to four acres. In holding this four-acre minimum unconstitutional, the court looked at the region in general and the growth of Easttown Township, where the tract was located. "Zoning," said the court, "must not and cannot be used by . . . officials as an instrument by which they may shirk their responsibilities. Zoning is a means by which a governmental body can plan for the future-it may not be used as a means to deny the future."42 If all townships in the area turned to large lot zoning, the result would be to deny building sites for a growing population. Arguments as to the preservation of the character of the area and its historic sites, alleviation of alleged sewage disposal problems, elimination of traffic problems, and similar arguments did not impress the Pennsylvania court. The fundamental issue was the exclusion of people:

The question posed is whether the township can stand in the way of natural forces which send our growing population into hitherto undeveloped areas in search of a comfortable place to live. We have concluded not. A zoning ordinance whose primary purpose is to prevent the entrance of newcomers in order to avoid future burdens, economic and otherwise, upon the administration of public services and facilities

\footnotetext{
39. $246 \mathrm{Md}$. at $365-66,228$ A. $2 \mathrm{~d}$ at $455-56$.

40. Board of County Supervisors v. Carper, 200 Va. 653, 107 S.E.2d 390 (1959).

41. 419 Pa. 504, 215 A.2d 597 (1965).

42. Id. at $527-28,215$ A.2d at 610 .
} 
can not be held valid. Of course, we do not mean to imply that a governmental body may not utilize its zoning power in order to insure that the municipal services which the community requires are provided in an orderly and rational manner.

. . . It is clear, however, that the general welfare is not fostered or promoted by a zoning ordinance designed to be exclusive and exclusionary. ${ }^{43}$

Easttown stood along the path of suburban development. Therefore, it could engage in orderly planning to accommodate growth but could not, to paraphrase the court, create a barrier to the future.

The commitment of the Pennsylvania court to the principles stated in National Land was reaffirmed in Appeal of Kit-Mar Builders ${ }^{44}$ in 1970. Existing zoning required two and three-acre minimums. The restrictions were held invalid and the rezoning approved because the township could not "keep out people, rather than make community improvements" and because population growth had to be dealt with directly without refusing "to confront the future by adopting zoning regulations that effectively restrict population to near present levels." 45

These decisions may not seem to have added much to the development of a civil liberties approach to zoning cases. They were brought by developers, and the motivating factor was the desire of the developers to make more money by building more expensive houses on smaller, but still expensive, lots. Even after these decisions, the lots which were left were hardly of the kind which would be occupied by persons of low or moderate incomes. Lots of one acre or more in size can, and likely did, accomodate the construction of houses designed to appeal largely to persons in the middle or upper middle income ranges. Nonetheless, the language employed by the Pennsylvania Court and the decisions reached have brought courts a great deal closer to the broader-based questions of the mid-I970's.

\section{Minimum House Sizes}

If the size of a lot necessarily limits the market for housing, quite obviously the size of the house on the lot does also. While it may be assumed that no one is likely to build a "cracker box" of a house on a city or suburban lot of one acre or larger, one way to ensure this is to require that each house contain a minimum number of square feet. This is, once again, the translation of typical subdivision restrictions into government-imposed regulations. Such limitations have generally been upheld in situations in

43. Id. at $532-33,215 \mathrm{~A} .2 \mathrm{~d}$ at 612 .

44. $439 \mathrm{~Pa} .466,268$ A.2d 765 (1970).

45. Id. at 474,268 A.2d at 768 . 
which the regulation is deemed to be reasonably related to health, safety and the general welfare. ${ }^{46}$

The leading case on the subject is Lionshead Lake, Inc. v. Township of Wayne, ${ }^{47}$ decided in 1952 by the New Jersey Supreme Court. It upheld minimum dwelling sizes in a rural township which contained a substantial number of vacation homes. The court held that the number of square feet in a dwelling had a relation to the health of the occupants and that the imposition of minimum sizes was within the police power. This was true even though the rural township lay "in the path of the next onward wave of suburban development." 48 The size of dwellings, said the court, "inevitably affects the character of the community and does much to determine whether or not it is a desirable place in which to live" and to hold otherwise might present a "grave danger . . . of the erection of shanties which would deteriorate land values generally to the great detriment of the increasing number of people who live in Wayne Township the year round. "49 It seems apparent that the decision was based largely on the threat to property values posed by vacation homes and the desire to prevent construction of shacks which would be occupied for only a small part of the year. The court felt that there was a clear relationship between the size of living quarters and the mental health of the occupants-another legitimate zoning goal. This is one of several cases to recognize the validity of zoning for minimum building size. 50

Lionshead Lake created quite a debate among some of the leading land use scholars of the day,,$^{51}$ and the issue continues to arise $e^{52}$ despite the fact that most of the cases on the subject have reinforced the general principle

46. For some early cases, compare Dundee Realty Co. v. City of Omaha, 144 Neb. 448, 13 N.W.2d 634 (1944), Flower Hill Bldg. Corp. v. Flower Hill, 199 Misc. 344, 100 N.Y.S.2d 903 (1950) and Thompson v. Carrolton, 211 S.W.2d 970 (Tex. Civ. App. 1948) with Senefsky v. Huntington Woods, 307 Mich. 728, 12 N.W.2d 387 (1943).

47. 10 N.J. 165, 89 A.2d 693 (1952), appeal dismissed, 344 U.S. 919 (1953).

48. Id. at $173,89 \mathrm{~A} .2 \mathrm{~d}$ at 697 .

49. Id. at $174-75,89 \mathrm{~A} .2 \mathrm{~d}$ at $697-98$.

50. See, e.g., Town of Lebanon v. Woods, 153 Conn. 182, 215 A.2d 112 (1965); DeMars v. Bolton Zoning Comm'n, 19 Conn. Supp. 24, 109 A.2d 876 (C.P. 1954), aff'd, 142 Conn. 580, 115 A.2d 653 (1955). But compare Appeal of Medinger, 377 Pa. 217, 104 A.2d 118 (1954) (invalidating a sliding scale of minimum floor space which varied according to the district) with Commonwealth v. McLaughlin, $168 \mathrm{~Pa}$. Super. Ct. 442, 78 A.2d 880 (1951) (upholding minimum space requirements for mobile homes). It should be noted that minimum building size requirements are not found in many ordinances, and where found, they are not particularly limiting. See $2 \mathrm{~N}$. WILLIAMS, supra note 21 , at $\$ 63.12$ (1974).

51. See Haar, Wayne Township: Zoning for Whom?-In Brief Reply, 67 HARV. L. REV. 986 (1954); Haar, Zoning for Minimum Standards: The Wayne Township Case, 66 HARV. L. REV. 1051 (1953); Nolan \& Horack, How Small a House?-Zoning for Minimum Space Requirements, 67 HARV. L. REv. 967 (1954).

52. See 2 N. WILliams, supra note 21 , at $\$ 60.01$; Cutler, Legal and Illegal Methods for Controlling Growth on the Urban Fringe, 1961 WIS. L. REV. 370; Williams \& Wacks, supra note 28. 
announced by Lionshead Lake. ${ }^{53}$ Although zoning has always been recognized as exclusionary to some degree, Lionshead Lake and the opposition it engendered focused attention on the social ramifications of zoning, particularly its economically and perhaps racially discriminatory nature. ${ }^{54}$

\section{Restrictive Use Limitations}

There is yet one other major instrument which reinforces the exclusionary tendencies of zoning-the practice of use limitations. Since Villiage of Euclid v. Ambler Realty Co.,55 many of the cases have centered around ordinances which zone for single-family residential use only. ${ }^{56}$ This not only keeps down population density but also serves to exclude people of lower and moderate incomes. It further excludes some persons of higher incomes, most young people and many older people, who are seeking residences in apartment houses or condominiums.

In a 1966 case, the Illinois Supreme Court was confronted with an ordinance which involved the definition of "family" and which defined it in a fairly typical way-relationship by blood, marriage or adoption, plus servants, and no more than one gratuitous guest. ${ }^{57}$ The ordinance was challenged by a woman who owned a house in a single-family district which was occupied by four young men as her tenants. The opinion by Justice Schaefer, striking down the definition, stated that other courts had emphasized "the single housekeeping unit aspect of the term, rather than the relationship of the occupants." 58 The Illinois court noted the mobility and instability of the modern family and held it impermissable for an ordinance to "penetrate so deeply as this one does into the internal composition of a single housekeeping unit." 59

53. See notes 46 \& 50 supra. See also Annot., Validity and Construction of Zoning Regulations Prescribing Minimum Floorspace or Cubic Content of Residence, 96 A.L.R.2d 1409 (1964).

54. See Pierro v. Baxendale, 20 N.J. 17, 29, 118 A.2d 401, 407 (1955) (in which the New Jersey Supreme Court indicated that Lionshead Lake's "very broad principles" "'may intensify dangers of economic segregation"); 2 N. WILLIAMS, supra note 21, at $\$ 63.03$; Haar, Zoning for Minimum Standards: The Wayne Township Case, supra note 51. See also Vickers v. Gloucester Township, 37 N.J. 232, 265, 181 A.2d 129, 140 (1962) (Hall, J., dissenting), appeal dismissed, 371 U.S. 233 (1963). But as Richard Babcock wrote:

The control of house size has raised the cry of 'economic segregation,' amounting to snobbery or 'aesthetics.' There is economic segregation in such minimum controls, but this should not shock us unless we are shocked by the entire principle of zoning. Zoning is full of examples of 'economic segregation,' none of which appear to disturb the critics or the courts.

Babcock, supra note 28, at 201. Babcock pointed out that the basic characteristic of a zoning ordinance involves classification which leads to segregation.

55. 272 U.S. 365 (1926). See notes 16-18 supra and accompanying text.

56. See E. BASSETT, ZONING 46-47 (1936).

57. City of Des Plaines v. Trottner, 34 Ill. $2 d$ 432, 216 N.E.2d 116 (1966).

58. Id. at 436,216 N.E. $2 d$ at 119.

59. Id. at 438,216 N.E. $2 d$ at 120 . 
However, an ordinance which was only slightly more liberal in its definition of "family" was subsequently approved by the United States Supreme Court in Village of Belle Terre v. Boraas. ${ }^{60}$ This provision had been attacked on several grounds: interference with the right to travel; interference with the right to enter and settle in a state; the barring of undesirable persons from the community; invasion of the right of privacy; and in general, that the restriction did not further a valid governmental interest and was not in accord with our experience as an open and egalitarian society. The ordinance did permit two unmarried people to live together, and the Court found that it was not necessary to allow more than that. Speaking for the Court, Justice Douglas found virtue in creating areas for "family" living within a city and restated that the police power "is not confined to elimination of filth, stench, and unhealthy places" and may be used to create "zones where family values, youth values, and the blessings of quiet seclusion, and clean air make the area a sanctuary for people."61 Justice Marshall wrote a strong dissent based on the invasion of the freedom of association and the right to privacy, and Justice Brennan also dissented. The decision was attacked in a number of law reviews on grounds generally relating to equal protection. ${ }^{62}$ Nonetheless, the decision seems likely to stand for some time to come, and it has served to promote Justice Douglas' view of the legitimacy of considering aesthetics in zoning. ${ }^{63}$

Boraas is noteworthy in that traditional zoning practices favoring single-family units and family living were sustained against an attack based on such constitutional arguments as the right to travel, freedom of association, the right of privacy and equal protection. However, the question of exclusion of people from a community was not squarely considered. Douglas' opinion focused on the validity of setting aside an area for families as they are traditionally thought of. He apparently did not believe that this type of zoning had any effect on people wanting to settle in the community-they could settle in some other zone. This, however, does not take into account

60. 416 U.S. 1 (1974). The ordinance permitted only one-family dwellings and excluded lodging, boarding, fraternity or multiple-dwelling houses. It defined "family" to mean one or more persons related by blood, adoption or marriage, or not more than two unrelated persons, living and cooking together as a single housekeeping unit. Id. at 2 . This ordinance may be compared to the ordinance at issue in the recent case of Moore v. City of East Cleveland, $97 \mathrm{~S}$. Ct. 1932 (1977), discussed at note 128 infra.

61. 416 U.S. at 9.

62. See, e.g., Note, Boraas v. Village of Belle Terre: The New, New Equal Protection, 72

MiCH. L. Rev. 508 (1974); Recent Development, 60 CoRNell L. REV. 299 (1975).

63. In Berman v. Parker, 348 U.S. 26, 33 (1954), Justice Douglas stated:

It is within the power of the legislature to determine that the community should be beautiful as well as healthy, spacious as well as clean, well-balanced as well as carefully patrolled. . . . If those who govern the District of Columbia decide that the Nation's Capital should be beautiful as well as sanitary, there is nothing in the Fifth Amendment that stands in the way. 
the problem of "bedroom" communities zoned entirely or almost entirely for single-family residential use.

A further aspect of Boraas is that it contained no element of discrimination against racial minorities or poor people. The plaintiffs were college students, and cases involving college students, whether in the context of communal-type living as here or fraternities or clubs, have never evoked particular sympathy from the courts. ${ }^{64}$ Thus, the Court was unimpressed by the constitutional arguments presented in Boraas in light of its particular factual context. This rather simple fact seems largely overlooked in the constitutionally based rhetoric which followed the decision.

As such, despite the attention accorded it, it is not clear that Boraas is as significant as it seemed to some when it was decided. While the decision leaves single-family zoning, along with its exclusionary effects, intact, it must be remembered that the situation involved no overtones of racial or economic discrimination. The decision offers little guidance in the context of single-family zoning which can and has been employed in such a way as to exclude minorities and the economically deprived. No mention was made of the use of such zoning to prohibit mobile homes or multi-family housing, and it is in this context that the constitutional issues which were raised in Boraas become more real as well as more apparent.

\section{From Mount Laurel TO Arlington Heights: YOU TAKE THE HIGH ROAD AND I'LL TAKE THE LOW ROAD}

This leads us to Mount Laurel ${ }^{65}$ and ultimately to Arlington Heights. ${ }^{66}$ These cases and others like them involve the exclusionary effects of zoning when applied to suburban areas of limited size and purpose. It has been noted that zoning, by its very nature, is exclusionary. ${ }^{67}$ This fact is of less apparent importance in a large, diversified city in which most conceivable uses are generally accommodated. But when a community develops in such a way as to limit its scope, either by happenstance or by design, the result is to exclude a great many uses and, from the standpoint of residential use, to exclude a great many people. Again, whether by happenstance or design, most of the people excluded are usually people of lesser economic ineans, and in America today, that means that a disproportionately high percentage

64. See, e.g., City of Schenectady v, Alumni Ass'n of Union Chapter, 5 App. Div. 2d 14, 168 N.Y.S.2d 754 (1957).

65. Southern Burlington County NAACP v. Township of Mt. Laurel, 67 N.J. 151, 336 A.2d 713 (1975), appeal dismissed, 423 U.S. 808 (1975). See notes 78-87 infra and accompanying text.

66. Village of Arlington Heights v. Metropolitan Housing Dev. Corp., 429 U.S. 252 (1977). See notes 95-123 infra and accompanying text.

67. See Babcock, supra note 28, at 201-04; cf. Sager, Tight Little Islands: Exclusionary Zoning, Equal Protection, and the Indigent, 21 STAN. L. REv. 767 (1969) (discussing certain forms of zoning as being exclusionary in nature). 
of them will be members of racial minorities. It should be recognized that the problem of exclusion pits two legitimate values against one another: the equal right of people to move freely and live in places of their choosing as opposed to the interest of society in employing the police power to promote the type of community that is desired by present inhabitants. This is a different issue from the old one of the police power versus property rights. It is the police power versus civil rights. Measured on the scale of judicial values in this country, as the cases have evolved over the past half century, ${ }^{68}$ this presents a much more serious problem.

This problem is highlighted by several Missouri cases. In City of Moline Acres v. Heidbreder ${ }^{69}$ the Missouri Supreme Court concluded that the Missouri statutes were not intended to enable a municipality to adopt a one-use district zoning ordinance encompassing the whole town. This decision struck a blow at the exclusionary effect of the satellite bedroom communities surrounding St. Louis. Bounded by the Mississippi to the east, the city of St. Louis and its minorities could be locked in by surrounding suburban communities to the west which circled north and south to meet the river. It could be encircled, that is, if the suburbs could zone for a single use-single-family residential-and further zone for lots and dwellings of substantial size. But Moline Acres did not last for long. Criticized by its own state court of appeals sitting in St. Louis, ${ }^{70}$ the Missouri Supreme Court

68. Without providing a laundry list of civil rights cases, it is sufficient to say the federal judicial system has followed a clear pattern in recent years in the protection of individual civil rights. Moreover, on limited occasions when the question of race was injected into the property or land use area, civil liberties generally were upheld. Shelley v. Kraemer, 334 U.S. 1 (1948), determined that racially restrictive covenants could not be enforced, and Barrows v. Jackson, 346 U.S. 249 (1953), denied recovery for damages allegedly resulting from the breach of such covenants. In Reitman v. Mulkey, 387 U.S. 369 (1967), a California constitutional amendment which guaranteed the right of private persons to sell real property to whomever they might choose was considered to be state action in the sense of providing authorization for private discrimination in housing and was therefore invalidated. Then, in Jones v. Alfred H. Maycr Co., 392 U.S. 409 (1968), it was held that all racial discrimination in the sale or rental of property was illegal. See also Sullivan v. Little Hunting Park, Inc., 396 U.S. 229 (1969); Hunter v. Erickson, 393 U.S. 385 (1969). However, in James v. Valtierra, 402 U.S. 137 (1971), the Court was not willing to go so far as to invalidate a California law which required that housing projects be approved by referendum where that law was neutral on its face and there was no showing that housing referendums are rejected because of racial prejudice or the desire to exclude minority groups. The desire of the United States Supreme Court to uphold land planning concepts and promote aesthetics within urban areas is illustrated in Berman v. Parker, 348 U.S. 26 (1954). This interest would appear not to conflict with the Court's efforts in protecting civil liberties. But what if land planning excludes minorities or adversely affects them by limiting the places they must live to areas not unlike those the planners sought to eliminate in Berman? That, of course, produced the conflict between otherwise commendable and seemingly equally acceptable values.

69. 367 S.W.2d 568 (Mo. 1963).

70. McDermott v. Village of Calverton Park, 447 S.W.2d 837 (Mo. Ct. App. 1969), rev'd, 454 S.W.2d 577 (Mo. 1970). 
recanted in McDermott v. Village of Calverton Park ${ }^{71}$ in 1970. In a mea culpa decision in which it expressed regret that Michigan, ${ }^{72}$ by following Moline Acres, had been led down the garden path, the Missouri Supreme Court decided that there were valid conditions under which a city could adopt a one-use zoning ordinance.

The federal Court of Appeals for the Eighth Circuit, which sits in St. Louis, did not agree. In United States $v$. City of Black Jack, Missouri, ${ }^{73}$ it was confronted with a situation involving an ordinance prohibiting the construction of new multiple-family dwellings. An organization wanted to construct facilities for low and moderate income families in Black Jack. The result was an action under the Fair Housing Act, Title VIII of the 1968 Civil Rights Act. ${ }^{74}$ Although the district court dismissed the complaint, it noted the virtually all-white composition of Black Jack, and the court of appeals quoted extensively from those findings. In invalidating the ordinance, the court stated that, under the provisions of Title VIII, the "plaintiff need make no showing whatsoever that the action resulting in racial discrimination in housing was racially motivated." 75 "Effect, and not motivation, is the touchstone, in part hecause clever men may easily conceal their motivations" and because a prima facie case had been shown by demonstrating a "racially discriminatory effect." "76 The test that the court employed was one of "ultimate effect," and the effect of the action by Black Jack was to prevent eighty-five percent of the blacks in St. Louis from living in Black Jack. Throughout the opinion, the court relied heavily on what it viewed to be the intent of the Fair Housing Act of $1968 .^{77}$

Soon after Black Jack, in Southern Burlington County NAACP v. Township of Mount Laurel, ${ }^{78}$ the New Jersey Supreme Court, relying on the New Jersey Constitution, ${ }^{79}$ overturned a town zoning plan which made no

71. 454 S.W.2d 577 (Mo. 1970).

72. Gundersen v. Village of Bingham Farms, 372 Mich. 352, 126 N.W.2d 715 (1964), followed Moline Acres.

73. 508 F.2d 1179 (8th Cir. 1974), cert. denied, 422 U.S. 1042 (1975).

74. 42 U.S.C. $\S \S 3601-3619$ (1970).

75. 508 F.2d at 1185 .

76. Id.

77. The Black Jack court's reliance on the "effects" approach in a Fair Housing Act case was predicated on the holding in Williams v. Matthews Co., 499 F.2d 819 (8th Cir.), cert. denied, 419 U.S. 1021 (1974). Although the developer in Williams professed to support integration, the court examined the effects of his actions in not selling property to blacks. The court stated that it would "look beyond the form of a transaction to its substance and proscribe practices which actually or predictively result in racial discrimination, irrespective of defendant's motivation." 499 F.2d at 826.

78. 67 N.J. 151, 336 A.2d 713 (1975), appeal dismissed, 423 U.S. 808 (1975).

79. N.J. ConsT., art. I, para. 1. 
provision for multi-family use ${ }^{80}$ The court accepted the proposition that the town regulations were not intended to exclude on the basis of race, and the decision was not predicated on the question of race discrimination. The court did note, however, that the effect was to prevent low and moderate income people from living there and it viewed the legal question as:

[W] hether a developing municipality ... may validly . . make it physically and economically impossible to provide low and moderate income housing in the municipality for the various categories of persons who need and want it and thereby . . . exclude such people from living within its confines because of the limited extent of their income and resources. ${ }^{81}$

It concluded that every municipality must make available a variety and choice of housing and must bear its "fair share of the present and prospective regional need." 82 In the absence of regional zoning which would allocate housing over a wide area, Mount Laurel would have to adopt appropriate zoning regulations and take whatever additional action is required to encourage "the fulfillment of its fair share." 83

Norman Williams, who has written ably and extensively on land use planning, viewed Mount Laurel as "the most important zoning case since Euclid -and indeed supersedes Euclid on one-third of its holding, having to do with residential building types," because it placed serious limitations on zoning and planning which exclude lower economic classes from finding housing in the suburbs. ${ }^{84}$ Of course, the decision did not "supersede" a United States Supreme Court decision, but insofar as New Jersey was concerned, it did have the effect of placing serious limitations on zoning and planning which resulted in excluding lower economic classes from housing in the suburbs. In addition, Mount Laurel had overtones similar to the school desegregation orders in that it seemed to contemplate that additional court action might be required to achieve the desired goal. ${ }^{85}$ In the sense that it involved movement and was aimed at breaking down housing patterns in

80. No provision was made for apartments, mobile homes or even attached townhouses. 67 N.J. at 163,336 A.2d at 719 .

81. Id. at $173-74,336 \mathrm{~A} .2 \mathrm{~d}$ at 724 .

82. Id.

83. Id. at 192,336 A. 2 d at 734 . The court did not provide a method or index for determining what constituted a "fair share." Presumably this question would be subject to later court tests by those who believed that less than a fair share had been provided for. See, e.g., Urban Leag. of Gr. New Brunswick v. Mayor \& Coun. Cartaret, 142 N.J. Super. 11, 359 A.2d 526 (1976).

84. Williams, Mt. Laurel, A Major Transition in American Planning Law, 27 LAND USE L. \& ZoNing Dig. No. 6, at 33, 33 (1975).

85. The opinion is somewhat ambiguous on this point in that the New Jersey Supreme Court drew back from the order of the trial court directing the township to conduct studies and provide a plan of affirmative public action intended to satisfy these needs. The supreme court found this to be too strong a remedy for the moment, because it felt the municipality should first have the opportunity to act without judicial supervision. Obviously, this leaves the way open to later judicial supervision if the action taken is unsatisfactory. 
order to arrive at an appropriate "mix" of social classes, it was also somewhat reminiscent of the busing cases.

The Mount Laurel decision was viewed as the new reality, and the philosophy underlying the decision was advocated by many of those writing in the field. The thinking prevalent at this time is best illustrated by a report of the American Bar Association Commission on Housing. ${ }^{86}$ The authors of the report advocate involving the judicial system in a manner similar to the way in which it was involved in school desegregation. The courts would require local governments to provide space for low income housing, and national and state instrumentalities would require local governments to plan for the construction of low income housing. The power of the law, both judicial and legislative, would be invoked to force compliance by municipalities; and municipalities which did not comply or which lagged behind by not meeting their "fair share" (as contemplated by Mount Laurel) would be required to take affirmative action with the courts perhaps

86. Housing for all Under law: New Directions in Housing, Land Use and PlanNiNG LAW (R. Fishman, ed. 1977). This comprehensive report includes the following observations and conclusions:

(1) Restrictive zoning practices contribute to the high cost of new housing, creating an economic barrier which reinforces existing patterns of racial segregation.

(2) Local governments have an affirmative duty to provide housing for lower and moderate income persons. The report suggests that local regulations which hamper the construction of low-income housing be removed and that incentives be offered to private developers. It is further suggested that planning be done on a regional, rather than local, basis.

(3) Procedural roadblocks such as restrictive standing requirements should be removed in order to facilitate legal challenges to zoning laws which prevent a municipality from providing its "fair share" of low-income housing. Judicial remedies must be comprehensive enough to make a meaningful change in existing housing patterns.

(4) Closer judicial scrutiny must be given to the administrative process in zoning, a process which often has led to highly subjective and unpredictable results.

(5) Modern and flexible planning techniques, such as planned unit developments, transferrable development rights, and special permits are encouraged where they will support housing opportunities for all income groups.

The conclusions of this report were generally supported by participants in a presentation on this subject at the annual meeting of the Association of American Law Schools in Houston in December of 1976. One speaker felt that if a housing project meets HUD criteria and secures the approval of that agency, yet is still excluded, the exclusion becomes suspect. Remarks by Herbert Franklin to the Section of Property, Association of American Law Schools (Dec. 27, 1976). This would result in a situation in which a court could direct a locality to cease excluding people, which in turn would produce judicial supervision on a case-by-case basis. Id. An attorney associated with HUD took issue with this position, stating that the competence of courts to supervise the development of new housing was doubtful. Remarks by Robert DeVoy to the Section of Property, Association of American Law Schools (Dec. 27, 1976). On the whole, however, Mt. Laurel gave rise to the opinion that the judiciary and legislature would actively intervene to force local governments to accept housing of all types and for all economic groups. The implications of Warth v. Seldin, 422 U.S. 490 (1975), on the subject of standing, and Washington v. Davis, 426 U.S. 229 (1976), on the subject of "discriminatory impact" were largely ignored. 
rewriting and supervising the implementation of the local comprehensive plan. ${ }^{87}$

The feeling that Mount Laurel represented the new trend was reinforced by Hills $v$. Gautreaux ${ }^{88}$ in which the Supreme Court affirmed a comprehensive metropolitan area plan ordered by the Seventh Circuit which was to remedy the segregated housing patterns in the Chicago area. The suit was brought by some black tenants and applicants for public housing who alleged that the Chicago Housing Authority and the federal government through HUD were violating their civil rights by maintaining existing segregated housing patterns. They wanted public housing available outside the city of Chicago in the suburban areas surrounding the inner city. The court of appeals, in an opinion written by former Justice Tom C. Clark, furthered the comparison between zoning and the school desegregation cases by devoting substantial space to a discussion of a school desegregation decision-Milliken v. Bradley. ${ }^{89}$ That case was important because it stated that solutions involving the metropolitan area would be employed only where it was appropriate to do so. ${ }^{90}$ On the other hand, Milliken implied that the result might be different if housing discrimination were involved..$^{91}$ The Gautreaux Court concluded that any effective remedial plan for the problem of housing patterns in the Chicago area would have to involve a metropolitan or suburban solution. ${ }^{92}$

87. Others who wrote on this general subject in the time after Mt. Laurel but before Arlington Heights adopted this general view. See Williams, supra note 84; Ackerman, The Mount Laurel Decision: Expanding the Boundaries in Zoning Reform, 1976 U. ILL. L.F. 1. But see Note, The Inadequacy of Judicial Remedies in Cases of Exclusionary Zoning, $74 \mathrm{MICH}$. L. REv. 760 (1976).

88. 425 U.S. 284 (1976), aff'g Gautreaux v. Chicago Housing Auth., 503 F.2d 930 (7th Cir. 1974).

89. 418 U.S. 717 (1974). The Supreme Court opinion of Justice Stewart also discussed Milliken at some length and made this important observation:

Although the Milliken opinion discussed the many practical problems that would be encountered in the consolidation of numerous school districts by judicial decree, the Court's decision rejecting the metropolitan area desegregation order was actually based on fundamental limitations on the remedial powers of the federal courts to restructure the operation of local and state governmental entities. That power is not plenary.

Gautreaux, 425 U.S. at 293. He also noted that, "The remedial decree would neither force suburban governments to submit public hearing proposals to HUD nor displace the rights and powers accorded local government entities under federal or state hearing statutes or existing land-use laws." Id. at 306.

90. An "inter-district violation" would justify imposition of inter-district desegregation, according to Milliken. But this response would not be proper if a constitutional violation occurred only within a single district. 418 U.S. at 744-45.

91. Justice Clark makes this observation in his opinion for the Seventh Circuit, 503 F.2d at 936. It is based partly on a footnote in the majority opinion by Chief Justice Burger in Milliken, 418 U.S. at 728 n.7, and in part on a statement in the concurring opinion by Justice Stewart, 418 U.S. at 754-55.

92. 503 F.2d at 936 . 
Having affirmed Gautreaux, the United States Supreme Court had presumably set the stage for a decision similar to those of the Eighth Circuit in Black Jack and the Seventh Circuit in Village of Arlington Heights v. Metropolitan Housing Development Corp..$^{93}$ Such an opinion might have adopted the view of the New Jersey court although possibly not going so far as to condemn exclusionary practices on the basis of the effect on socioeconomic classes. But such was not to come. The Supreme Court had affirmed the notion that the Chicago Housing Authority should look to the suburbs for places to build public housing and thereby break down segregated housing patterns. But what the Court gave in 1976, it partly took away in 1977, as it told the suburbs in effect that as far as equal protection was concerned they could keep out multi-family housing if that was their pleasure as long as there was no intent to discriminate racially. This was the result of the reversal on appeal of the Seventh Circuit's decision in Arlington Heights, ${ }^{94}$ and it considerably reduced the possibilities for the Chicago Housing Authority to fulfill the mandate given it in Gautreaux.

\section{Arlington Heights AND THE CURRENT IMPLICATIONS OF EXCLUSION}

Although Arlington Heights has greatly simplified the task of determining what is left on the federal level of the "exclusionary zoning" argument, it is still profitable to examine the undeveloped aspects of the case. The case arose from the refusal of Arlington Heights, a highly segregated ${ }^{95}$ village outside of Chicago, to rezone a fifteen-acre parcel to permit the construction of subsidized multi-family dwellings by a non-profit housing developer. An action was filed by the developer and three blacks who wished to live in Arlington Heights, alleging that the village's refusal to rezone violated their rights under the Civil Rights Act, ${ }^{96}$ the Fair Housing Act of $1968,{ }^{97}$ and the fourteenth amendment. The district court denied relief on the grounds that the Fair Housing Act was inapplicable and that the refusal to rezone constituted economic, but not racial, discrimination..$^{98}$ The court concluded that the existing zoning served the legitimate objective of preserving property values and the integrity of the village's zoning plan. ${ }^{99}$

93. 517 F.2d 409 (7th Cir. 1975), rev'd, 429 U.S. 252 (1977). See text accompanying notes 100-02 infra.

94. 429 U.S. 252 (1977).

95. With a population that is $99.9 \%$ white, Arlington Heights is the most residentially segregated community in the Chicago metropolitan area among municipalities with more than fifty thousand residents. 517 F.2d at 414 .

96. 42 U.S.C. $\S \S 1981-1983$ (1970).

97. 42 U.S.C. $\S 3601-3631$ (1970).

98. 373 F. Supp. 208, 210 (N.D. Ill. 1974).

99. Id. at 211. 
In an opinion issued before the Supreme Court's decision in Washington v. Davis, ${ }^{100}$ the Court of Appeals for the Seventh Circuit reversed on the ground that the refusal to rezone had a racially disproportionate impact and therefore could be upheld only if it were shown that a compelling public interest necessitated the decision. ${ }^{101}$ The court rejected the argument that either the maintenance of the integrity of the zoning plan or the protection of neighborhood property values is a compelling state interest. ${ }^{102}$ Because it seemed unnecessary, the court failed to address the issue of the applicability of the Fair Housing Act.

On a writ of certiorari, the Supreme Court reversed the circuit court, reaffirming the principle that proof of racially discriminatory intent is required to show a violation of the fourteenth amendment. ${ }^{103}$ Because the village had adopted its zoning policies long before the developer sought rezoning and had applied its zoning policies consistently, the Court concluded that no discriminatory purpose lay behind the refusal to rezone. ${ }^{104}$ The court of appeals' finding that the decision of the village resulted in a discriminatory "ultimate effect" was viewed as insignificant. 105

In the midst of the generally gloomy reception given the Arlington

100. 426 U.S. 229 (1976). The case involved the validity of a written verbal ability test developed by the Civil Service Commission which was employed by the District of Columbia Metropolitan Police Department to screen its recruits. The failure rate for black recruits was over four times as high as the rate for whites. The Court announced that this racially disproportionate impact was insufficient to establish a denial of equal protection; rather, the touchstone of racial discrimination is racially discriminatory intent or purpose. Id. at 242-43.

101. 517 F.2d at 409.

102. Id. at 415 .

103. 429 U.S. at 264-65.

104. Unlike in Washington v. Davis, the Court in Arlington Heights set forth a catalog of factors which may tend to show an intent to discriminate:

(1) official action which "bears more heavily on one race than another," 429 U.S. at 266 (citing Washington v. Davis, 426 U.S. at 242);

(2) a clear pattern demonstrating racial bias which "emerges from the effect of the state action" and is "unexplainable on grounds other than race" even though the legislation appears neutral, 429 U.S. at 266 (citing Gomillion v. Lightfoot, 364 U.S. 339 (I960); Lane v. Wilson, 307 U.S. 268 (1939); Guinn v. United States, 238 U.S. 347 (1915); and Yick Wo v. Hopkins, 118 U.S. 356 (1886));

(3) "the historical background of the decision . . ., particularly if it reveals official actions with apparent invidious purposes," 429 U.S. at 267 (citing Griffin v. County School Bd:, 377 U.S. 218 (1964); Lane v. Wilson, 307 U.S. 268 (1939); and Davis v. Schnell, 81 F. Supp. 872 (S.D. Ala. 1949), aff'd per curiam, 336 U.S. 933 (1949));

(4) the sequence of events leading up to the decision by governmental authority, 429 U.S. at 267 (citing Reitman v. Mulkey, 387 U.S. 369, 373-76 (1967); and Grosjean v. American Press Co., 297 U.S. 233, 250 (1936));

(5) departures from the normal procedural or substantive process by the instrumentality making the decision, 429 U.S. at $267 \mathrm{n} .17$ (citing Dailey v. City of Lawton, Oklahoma, 425 F.2d 1037 (10th Cir. 1970)) and the legislative or administrative history of the provision, 429 U.S. at 268.

105. 429 U.S. at 268 . 
Heights decision, many observers failed to note that the Court remanded the case for resolution of the Fair Housing Act issue. The Court in Washington v. Davis had expressly noted that disproportionate impact may still be sufficient to make out a violation of Title VII, ${ }^{106}$ and the application of this standard to the Fair Housing Act was an open question. ${ }^{107}$ As already seen, the Eighth Circuit in Black Jack ${ }^{108}$ had employed the disproportionate impact standard, stating that such a standard was in keeping with the policy objectives underlying the Act. At least two other cases consistent with Black Jack had been decided before the remand of Arlington Heights, ${ }^{109}$ and it seemed clear that the Seventh Circuit's disposition of the remanded Fair Housing Act question would largely determine what, if anything, was left on the federal level for developers and prospective residents who challenge a municipality's exclusionary zoning practices.

It was in this critical context that the Seventh Circuit recently determined that, at least under some circumstances, a violation of the Fair Housing Act can be established by a showing of discriminatory effect without a showing of discriminatory intent. ${ }^{110}$ The court declined; however, to hold that proof of disproportionate impact is sufficient, of itself, to establish a violation. Using a four-part inquiry ${ }^{111}$ into the circumstances under which the disproportionate impact arose, the court did not actually determine that a violation existed, but rather held that the Fair Housing Act is violated here "if there is no land other than plaintiff's property within Arlington Heights which is both properly zoned and suitable for federally subsidized low-cost housing ...."112 The case was remanded to the district court for a determination of this issue, with the order that the lower court grant the relief requested by the plaintiff unless the village shows that a suitable alternative site is available. ${ }^{113}$

106. 426 U.S. at $246-52$.

107. Compare Comment, Applying the Title VII Prima Facie Case to Title VIII Litigation, 11 Harv. C.R.-C.L. L. Rev. 128 (1976), with 88 Harv. L. Rev. 1613 (1975).

108. See notes 73-77 supra and accompanying text.

109. Smith v. Anchor Bldg. Corp., 536 F.2d 231 (8th Cir. 1976); Kennedy Park Homes Ass'n., Inc. v. City of Lackawanna, 436 F.2d 108, 114 (2d Cir. 1970) (dictum), cert. denied, 401 U.S. 1010 (1971). Contra, Boyd v. Lefrak Organization, 509 F.2d 1110 (2d Cir. 1975).

110. Metropolitan Housing Dev. Corp. v. Village of Arlington Heights, 558 F.2d 1283 (7th Cir. 1977).

111. Id. at 1290-93. The four factors examined were: the strength of the plaintiff's showing of discriminatory effect, whether there is some evidence of discriminatory intent, even if not enough to satisfy the constitutional standard of Washington v. Davis, the defendant's interest in taking the action complained of, and whether the plaintiff seeks to compel the defendant to affirmatively provide housing for members of minority groups or merely to restrain the defendant from interfering with individual property owners who wish to provide such housing. Id. at 1290 .

112. Id. at 1294.

113. The burden of identifying a parcel within Arlington Heights which is both properly zoned and suitable for low-cost housing under federal standards was placed on the Village. Id. 
The continued availability of the Fair Housing Act to zoning plaintiffs does not, however, mitigate the significance of the Supreme Court's opinion in Arlington Heights. The case represents to a large extent a reaffirmation of the old Euclid ${ }^{14}$ case as reinforced by more recent decisions such as Boraas. ${ }^{115}$ It rejects the underlying concept of Mount Laurel ${ }^{116}$ that, as a constitutional matter, the impact on the region and the central city as a result of exclusionary zoning in the suburbs is enough to invalidate the scheme due to economic discrimination having racial implications thus permitting the courts to intervene and force a rezoning for a variety of residential uses. In so doing, the Court has eschewed an active role for itself and for the lower federal courts. Faced with the question of whether the federal court system would take on the activist role it occupied in school desegregation matters in the 1960's, it has answered negatively. It was a choice which would have proven momentous had the Court been of a mind to take on the task. It would have involved court-directed reordering of zoning laws in suburban communities and court-ordered economic and racial integration in housing patterns. It would have ultimately realigned our society by forcibly reassigning the places where lower income people live.

It is important to understand, however, that this result will not prevent a federal court from invalidating a zoning law or action taken by zoning authorities in a situation in which it could use one or more of the criteria enunciated in Arlington Heights to show a discriminatory purpose. ${ }^{117}$ In cases based on Golden v. Planning Board ${ }^{118}$ and Construction Industry of Sonoma County v. City of Petaluma ${ }^{119}$ involving timed and sequential growth controls, it would appear that the question (in the federal courts) is whether the restrictions on residential uses are too exclusionary in light of the community objective of orderly growth. In other words, it would again depend largely on traditional police power considerations. ${ }^{20}$ The constitu-

at 1295. In his concurring opinion, Chief Judge Fairchild noted that the district court had identified nine parcels that were suitably zoned, prompting him to disagree with the majority's decision to shift the burden to the Village. Id.

114. See notes 16-18 supra and accompanying text.

115. See notes 60-64 supra and accompanying text.

116. See notes 78-87 supra and accompanying text.

117. This preserves the validity of such rulings as that by the Tenth Circuit in Dailey v. City of Lawton, Oklahoma, 425 F.2d 1037 (10th $\mathrm{Cir}$. 1970), in which the court invalidated a zoning ordinance where there had been a significant departure from normal procedure by the municipality in making the zoning decision.

118. 522 F.2d 897 (9th Cir. 1975), cert. denied, 424 U.S. 934 (1976). See note 22 supra.

119. 30 N.Y.2d 359, 334 N.Y.S.2d 138, 285 N.E.2d 291 (1972). See note 22 supra.

120. One little-discussed zoning question which generally is decided under the police powers is that of mobile homes. Courts are in disagreement on this matter. In Vickers v. Township Comm. of Gloucester Township, 37 N.J. 232, 181 A.2d 129 (1962), cert. denied, appeal dismissed, 371 U.S. 233 (1963), the New Jersey Supreme Court upheld the exclusion of mobile homes from a rural township of about twenty-three square miles, although the case is chiefly 
tional "right to travel" issue presumably remains, and a community which became too exclusionary could have its plan invalidated on that basis. ${ }^{121}$ Nonetheless, Arlington Heights must permit advocates of such sequential growth plans to breathe easier.

It is also important to understand that this decision did not overturn Mount Laurel. Since the decision in that case was based on the New Jersey Constitution, ${ }^{122}$ it is still the law in New Jersey and other state jurisdictions could take the same approach. Its importance as precedent has been diminished considerably, however, since a state supreme court following the New Jersey precedent will have to conclude, either that zoning which has an economically or racially discriminatory effect is unlawful under its own state constitution, regardless of what the United States Supreme Court may think, or that single-family use districts are beyond the scope of the state police power. The second possibility obviously remains, and precedents of other states could be followed. ${ }^{123}$ The first possibility remains available, but seems improbable after Arlington Heights, since apparently the United States Supreme Court does not ascribe to the theory that zoning which has an economically or racially discriminatory effect denies equal protection. The states are more likely to be influenced by the United States Supreme Court than by New Jersey's.

\section{CONCLUSION}

For a time it appeared that the new reality of zoning would be Mount Laurel and cases like it. But the new reality of Mount Laurel, after

notable for the dissenting opinion of Justice Hall, whose views presaged his majority opinion in Mt. Laurel. In Town of Glocester v. Olivo's Mobile Home Court, Inc., 111 R.I. 120, 300 A.2d 465 (1973), a limitation on the number of mobile homes was held to be an invalid exercise of the police power. Courts have often used a nuisance rationale to uphold exclusionary ordinances. See 1 R. ANDERSON, AMERICAN LAW OF ZONING \& 11.49 (1968). This attitude appears to be changing. See Bristow v. City of Woodhaven, 35 Mich. App. 205, 192 N.W.2d 322 (1971).

121. On the right to travel question, see Note, Freedom of Travel and Exclusionary Land Use Regulations, 84 YALE L.J. 1564 (1975). While Crandall v. Nevada, 73 U.S. (6 Wall.) 35 (1867) is an early case dealing with the freedom to travel, the case generally associated with this question is Edwards v. California, 314 U.S. 160 (1941), which involved an attempt by California to prohibit the influx of indigents into the state. That decision was based on the interstate commerce clause. The Yale Note indicates that freedom to travel might also exist as an independent right based on a denial of equal protection. See Shapiro v. Thompson, 394 U.S. 618 (1969). Generally, exclusionary zoning ordinances are invalidated as overextending the police power, as we have seen, although the federal district court which invalidated the Petaluma plan held that the plan violated the right to travel. Construction Indus. Ass'n v. City of Petaluma, 375 F. Supp. 574 (N.D. Cal. 1974), rev'd, 522 F.2d 897 (9th Cir. 1975) (reversed for lack of standing), cert. denied, 424 U.S. 934 (1976). Despite the reversal of that case by the Ninth Circuit, the argument would seem to remain viable.

122. Justice Hall stated for the majority in Mt. Laurel that the substantive due process and equal protection provisions of the New Jersey Constitution "may be more demanding than those of the federal Constitution." 67 N.J. at 175, 336 A.2d at 725.

123. In addition to Mt. Laurel, see Gundersen v. Village of Bingham Farms, 372 Mich. 352, 126 N.W.2d 715 (1964) and Appeal of Girsh, 437 Pa. 237, 263 A.2d 395 (1970). 
Arlington Heights, has been displaced for the most part by the old reality. While issues framed more in terms of civil liberties than the taking of private property will probably continue to be asserted, the result in Arlington Heights is to limit this development. But Arlington Heights was not as unpredictable in its outcome as some may have thought. As stated earlier, it comes from a Court which is seemingly much less inclined to venture into societal restructuring by the judiciary than its predecessor of the previous decade. Secondly, the key elements of the decision represent a clear strain of thought running back to Euclid which recent cases have served to reinforce. To be specific, the Gautreaux affirmance ${ }^{124}$ states that local governments remain free to exercise their land use powers and are not required to submit housing proposals to HUD. ${ }^{125}$ Approval of housing proposals may be submitted to the voters under James $v$. Valtierra, ${ }^{126}$ despite the fact that this may lead to a veto of such projects. Further, Warth v. Seldin ${ }^{127}$ limited the persons attacking such local ordinances to individuals having a clearly justiciable interest in the outcome. Boraas ${ }^{128}$ upheld the

124. Hills v. Gautreaux, 425 U.S. 284 (1976).

125. The Court stated:

In contrast to the desegregation order [in Milliken v. Bradley] a metropolitan relief order directed to HUD would not consolidate or in any way restructure local governmental units. The remedial decree would neither force suburban governments to submit public housing proposals to HUD nor displace the rights and powers accorded local government entities under federal or state housing statutes or existing land-use laws. The order would have the same effect on the suburban governments as a discretionary decision by HUD to use its statutory powers to provide the respondents with alternatives to the racially segregated Chicago public housing system created by CHA [Chicago Housing Authority] and HUD.

425 U.S. at 305-06.

126. 402 U.S. 137 (1971), which upheld a California constitutional provision requiring approval by local voters of public low-rent housing projects. Without saying so, this case demonstrates favoritism for the requirement of a racially discriminatory intent as opposed to the discriminatory impact test. The law was racially neutral on its face, the Court reasoned, since the housing could be occupied by anyone who qualified. Cf. City of Eastlake v. Forest City Enterprises Inc., 426 U.S. 668 (1976) (delegation of legislative powers to the people through the use of a referendum does not require the establishment of standards for guidance).

127. 422 U.S. 490 (1975). Persons or corporations not residing in the municipality and who showed no injury resulting from the zoning practices were held to lack standing to attack the legality of the ordinance. The Court remarked that the "inability to reside in Penfield is the consequence of the economics of the area housing market, rather than of respondents' assertedly illegal acts." Id. at 506 .

128. Village of Belle Terre v. Boraas, 416 U.S. 1 (1974). See notes 60-64 supra and accompanying text. It is useful to compare Boraas with the recent case of Moore v. City of East Cleveland, 97 S. Ct. 1932 (1977). East Cleveland's ordinance differed from that adopted by the Village of Belle Terre in that the latter affected only unrelated individuals. The East Cleveland case involved lineal descendants (son and grandsons living with grandmother). In a 54 decision, the Court held that the East Cleveland ordinance was violative of due process in that it had only a tenuous relationship with the police power and sliced deeply into family association with particular reference to the "nuclear family," that is, "the tradition of uncles, aunts, cousins, and especially grandparents sharing a household along with parents and children" which tradition "has roots equally venerable and equally deserving of constitutional recognition." $97 \mathrm{~S}$. Ct. at 1938-39 (Powell, J., for the majority). Despite the fact that there were four 
concept of the family, and particularly the single-family concept, as a value which zoning could legitimately protect as against arguments based on the exclusionary effect. In so doing, it also reinforced the legitimacy of aesthetics as a valid consideration of the public welfare, to which Berman $v$. Parker ${ }^{129}$ had given expression. And in all of this, the Court was reaffirming once again the underlying concept of Euclid that while zoning can be too exclusionary and thus become an arbitrary exercise of the police power, it is legitimate to exclude in order to protect higher uses and, particularly, to protect single-family residential uses. ${ }^{130}$ Running throughout is a common thread which accepts the exclusionary basis of zoning under the police power and which requires a showing of a racially discriminatory intent or purpose, a clear interference with the right to travel or a direct violation of a constitutionally protected right such as privacy, before the Court will be willing to invalidate the action taken on some basis other than the traditional police power considerations.

Since the Court will receive ample criticism for Arlington Heights, it is perhaps appropriate to conclude with a few observations in its defense. The Court has not departed from its rather consistent view of zoning over the last half-century. If zoning, as an arm of planning, has any legitimacy at all, the concept of exclusion has to be accepted because that is precisely what it does. This does not validate a racially discriminatory purpose, and the Court has clearly recognized this. But to say that the impact of permitting expensive homes in suburban areas is racially discriminatory would have the effect of undercutting legitimate planning efforts and rendering uncertain the legal status of such areas. Their status, and what they would have to do to achieve racial balance, would ultimately involve the courts in the entire land-use planning process in many if not most metropolitan areas-a process which courts are ill-equipped to undertake on a long-term, comprehensive basis. Perhaps, then, the Court's reluctance to plunge the federal system into this milieu was motivated at least partly by a recognition that this is not the business of the courts and that courts are not structured to perform such tasks with much effectiveness. Moreover, it would seem that

dissents in the case (one of which by Chief Justice Burger was on the technical point that the plaintiffs did not seek a variance), it would appear that the stringent wording of the East Cleveland ordinance clearly carried the "single family" definition too far and that this decision has relatively little effect on Boraas. Perhaps the strength of the Boraas decision is underlined by the fact that four dissents, three of which were individually written, could be mustered to support a provision that amounted to an attack on the family itself. Despite the Court's discussion of the "nuclear family," it must be observed that the situation of a grandchild living in a family unit with a grandmother, or a nephew living with his uncle or aunt, has never been a particularly unusual occurrence in our society.

129. 348 U.S. 26, 33 (1954). See note 63 supra.

130. The Court in Euclid quoted from Illinois and Louisiana cases which specifically spoke in terms of "exclusion." 272 U.S. 365, 392-93 (1926). 
the Court's decision was motivated at least in part by the fact that the constitutional issues in terms of racial discrimination were hazy at best. Expensive suburbs are exclusionary because they are expensive, which relates to race only in the sense that this limits the market to a small number of successful minority business and professional persons. But many whites are also limited economically and there would be a rather substantial constitutional burden to bear in concluding that the mere act of purchasing a house in an affluent area is an act of racial discrimination.

The argument will be made that the Court failed to live up to the expectations of those who are most dependent upon it-the poor, the helpless, the minorities and the underprivileged. But the Court has sought on many occasions to uphold their rights and advance the reconciliation of their needs. Courts reach a point when they can effectively do no more, when solutions to problems have to be found by governmental agencies existing for that purpose. Courts can and do re-orient society through the expression of new constitutional concepts and policies. But neither the Supreme Court nor the federal court system can very effectively undertake the administrative task of reorganizing the living patterns of the entire nation. That is a task for the Congress, various federal agencies and the executive branch. It is a task which can best be accomplished through federal housing legislation, civil rights legislation and incentives of various kinds. The Court has sought to restrict the role of the federal judiciary. But in so doing, it has done no more than leave the work to those who have the power and the duty to perform it. 